Review article

Received: 19 Jun 2020

Revised: 7 Jul 2020

Accepted: 14 Jul 2020

\author{
Marcjanna WRZECIŃSKA (D), Ewa CZERNIAWSKA-PIĄTKOWSKA
}

\title{
SPECIFIC CHARACTERISTIC OF SHEEP'S MILK AND PRO-HEALTH PROPERTIES DEPENDING ON THE SOMATIC CELLS COUNT
}

\author{
Department of Ruminant Science, West Pomeranian University of Technology in Szczecin, Poland
}

\begin{abstract}
Sheep milk is a valuable product due to its properties and composition. It is richer in high-quality protein and contains more nutritional value compared to the milk of other ruminants. Raw milk is characterized by a lack of enzymatic activity and a lack of pathogenic microorganisms. Milk also has a high content of minerals. For this reason, sheep's milk is a good raw material for the dairy industry and the production of fermented milk drinks as well as cheese. During lactation, the content of individual milk ingredients and milk yield fluctuate, which translates into the nutritional value of the product. Also, the content of somatic cells in milk is significantly different between the peak and the end of lactation of animals. The increase in cellular elements is a major indicator of mammary gland infection. The cause of mastitis is bacterial infection or mechanical teat damage. Inflammation of the mammary gland is a serious problem for dairy farmers due to the health and economic aspects of this disease, which is the main cause of slaughtering ewes and the fall of many animals, as well as enforcing the cost of healing females, and the obtained milk is utilized. It is estimated that up to $60 \%$ of sheep in herds can suffer from asymptomatic mastitis, which is a serious problem for the dairy industry. That is why research is important to analyze the amount of somatic cells in milk.
\end{abstract}

Key words: sheep's milk, mastitis, dairy industry.

\section{INTRODUCTION}

Sheep's milk is a perfect raw material for cheese and fermented beverages. Compared to other ruminants' milk, it contains much more nutrients as well as minerals and vitamins. It also has a higher calorific value compared to cow's milk (Balthazar et al. 2017). Fermented milk drinks are free from thickeners, because sheep's milk is rich in dry matter (share up to $18 \%$ ). Fatty acids of sheep's milk are characterized by a higher content of shorter chain acids (mainly caprylic acid), which improves product digestibility (Danków and Pikul 2011).

Corresponding author: Marcjanna Wrzecińska, Department of Ruminant Science, West Pomeranian University of Technology in Szczecin, 29 Klemensa Janickiego, 71-270 Szczecin, Poland, e-mail: marcjanna.wrzecinska07@onet.pl 


\section{EWE'S MILK}

Milk should be characterized by a lack of enzymatic activity and a lack of pathogenic microorganisms. An increase in the number of somatic cells has a negative effect on the content of individual components of sheep's milk, which results in poorer quality dairy products and also affects pasteurization of milk (Le Maréchal and Thiéry 2011). Unequal milk composition has a significant impact on the quality of sheep's cheese (Pavić et al. 2002). The product parameters depend mainly on the fat and lactose content as well as on the coagulating properties (including rennet coagulation time and curd hardening) of the sheep's milk used. The high somatic cell count (SCC) in milk directly affects renal coagulation, which affects cheese production (Villalobos et al. 2015).

Cellular elements are mainly leached epithelial cells of the gland and leukocytes (Sharma et al. 2011). During lactation sheep have a difference in their SCC levels in milk. With the onset of milk secretion, there is an increase in the number of somatic cells, just as it did during the dry period. The largest number of leukocytes with multiform nuclei are sheep colostrum, and the largest amount of macrophages is observed in the middle stage of lactation. As the lactation progresses, the number of cellular elements changes (Olechnowicz and Jaśkowski 2005). The increase in SCC levels in sheep's milk can be caused not only by the lactation phase, but also by infection or stress. Moreover the number of somatic cells in milk increases with the age of the sheep (Pirisi et al. 2000). The main indicator of cow udder infection is the high content of cellular elements, but in smaller ruminants the high level of SCC does not always inform about infections, because in sheep the number of somatic cells in milk increases with increasing lactation and with age of animals (Sharma et al. 2011, Petlane et al. 2013). Therefore, animals with higher SCC levels should be tested for pathogens that cause mastitis (Petlane et al. 2013).

\section{MASTITIS}

Mastitis is a serious disease and at the same time a problem for breeders (Fernández-Garayzábal et al. 1998). It can be caused by teat injury, chemical irritation or infection, which is the most common cause of the disease (Pawlik et al. 2010). The defending animal's response to penetrating pathogens is mainly swelling of the mammary gland, which results from the filtration of plasma through blood vessels. Extending them allows leukocytes to pass into milk to prevent progressive infection and stop pathogens. An important role in the body's response to pathogenic microorganisms is played by neutrophils, macrophages and eosinophils, which phagocytic microorganisms (Pawlik et al. 2010). Physico-chemical and bacteriological changes occur in the milk of sheep suffering from mastitis (Sharma et al. 2011). It is characterized by reduced milk yield as well as poorer quality (Leitner et al. 2003, Merin et al. 2004). In this milk, a decrease in fat, protein as well as lactose content and an increase in the number of somatic cells is also observed (Petlane et al. 2013). Mastitis occurs in two conditions clinical and subclinical. The clinical form is characterized by pronounced lesions of the gland, which is clearly swollen, red, and purulent secretion seeping from the teats is often visible. A damaged gland often does not resume its work (Mørk et al. 2007). In sheep and other small 
ruminants, severe clinical mastitis can develop into gangrene lesions that cause tissue destruction and even death of individuals (Le Maréchal and Thiéry 2011). In milk, macroscopic changes occur in the form of flocs. Staphylococci, streptococci and Escherichia coli are especially pathogens of this form. The subclinical state does not give visible symptoms, which results in latent infection (Ergün et al. 2009). The main pathogens of the described form are coagulase-negative staphylococci (CNS) (Olechnowicz and Jaśkowski 2005).

Milk obtained from sheep suffering from mastitis is characterized by a lower content of nutrients such as fat and protein. Infection also causes an increase in the content of somatic cells in milk (Petlane et al. 2013). Such milk has a lower concentration of lactose, which is associated with a higher content of albumin and whey, which results from the degradation of casein (Merin et al. 2004). Mastitis in sheep reduces milk yield and quality, which translates into higher economic losses than is the case with cattle due to the use of high-quality sheep's milk in the dairy industry for cheese production (Fernández-Garayzábal et al. 1998, Leitner and et al. 2003, Merin et al. 2004).

The composition of sheep's milk may vary depending on the breed, age and lactation stage. Also, the increase in the number of somatic cells has an effect on milk composition, which may vary depending on the pathogen causing mastitis (Le Maréchal and Thiéry 2011). Some bacteria cause only a slight change in the composition of milk, as is the case with Corynebacterium bovis. In turn, mammary gland inflammation due to Streptococcus agalactiae is associated with a decrease in protein content, which results from proteolytic processes occurring in milk. In contrast, Staphylococcus aureus causes a decrease in lactose content (Le Maréchal and Thiéry 2011). That is why it is very important in dairy animals to control the condition of the mammary glands, because each infection is associated with a reduced milk yield, but also in milk there are changes in the content of nutrients that are important, e.g. when rearing lambs (Rozbicka-Wieczorek et al. 2014) .

Staphylococcus aureus, Streptococcus agalactiae, Streptococcus uberis, Staphylococcus epidermidis and Escherichia coli are most frequently isolated from milk from sheep with mastitis. (Las Heras et al. 2002). The most common cause of bacterial mastitis is coagulase-negative staphylococci (CNS) (Mørk et al. 2007). Probably the second group of pathogens responsible for inflammation of the gland in sheep are microorganisms of the genus Streptococcus (Las Heras et al. 2002). Escherichia coli is also a frequently isolated microorganism (Mørk et al. 2007). S. aureus infections are among the most common caused by staphylococci as well as other pathogens isolated from milk obtained from infected glands (Rainard et al. 2003). This microorganism is most often associated with the clinical form of mastitis and can produce exotoxins, which are leukotoxins that selectively destroy phagocytic cells. These toxins do not destroy the pasteurization process, which contributes to the greater pathogenicity of staphylococci (Rainard et al. 2003). Staphylococcus bacteria are often resistant to antibiotics, which is a growing problem (Niedziela et al. 2012).

Mastitis can also be caused by Gram-negative Escherichia coli that inhabit the gastrointestinal tract of the animals. Mastitis caused by E. coli or other microorganisms of the Enterobacteriaceae family is called coliform mastitis. E. coli is an environmental pathogen that lives in animal litter and faeces (Markiewicz 2013). 


\section{TEST}

To prevent animal infections, first of all, hygiene rules should be observed during milking, as well as the cleanliness of milking machines and animal udders (Bergonier et al. 2003). Raw milk obtained from various mammalian species is an ideal breeding ground for microbial growth. Also, sheep's milk itself contains its own microbiological flora, ie mainly Gram-positive lactic acid bacteria giving the organoleptic characteristics of the product. Raw milk can also include psychrotrophic bacteria that can reproduce at low temperatures, which get into the product through contamination. Due to the presence of these microorganisms and Salmonella, milk and its products must be pasteurized. This allows you to get rid of microorganisms that can cause infections in people (Jarosińska et al. 2014).

Inflammation of sheep's mammary gland is one of the most serious causes of slaughtering ewes and economic losses, which in addition to the fall of animals also includes medical costs (Mørk et al. 2007, Watkins and Jones 2007). Mastitis reduces the nutrient content of milk, as well as a decrease in milk yield. Milk obtained from sheep suffering from mastitis is characterized by a lower content of fat, lactose and casein. However, the content of whey protein, albumin as well as the number of somatic cells increases (Merin et al. 2004). The presence of pathogenic bacterial flora in milk obtained from sheep suffering from mastitis poses a threat to consumer health (Bianchi et al. 2004).

In order to reduce the risk of milk contamination, it is necessary to take care of hygiene during milking, i.e. keep milking equipment and udder of dairy animals clean. During unsanitary milking, milk can become contaminated with microorganisms from litter, soil, water and even animal faeces. Milk contaminating bacteria, such as Pseudomonas spp., Produce proteolytic and lipolytic enzymes that contribute to the formation of milk defects such as changes in the physicochemical properties of the product (Ekici et al. 2004, Jarosińska et al. 2014).

\section{CONCLUSION}

Sheep milk is a valuable raw material for the dairy industry due to pro- health properties of ewes milk and rich composition and content of minerals. For this reason, sheep's milk is a good raw material to the production of fermented milk drinks as well as cheese. The content of individual ingredients and milk yield vary depending on the lactation phase, animal nutrition and mammary gland infections. Mastitis is a serious disease entity that involves health and economic aspects

\section{REFERENCES}

Balthazar C.F.,Pimentel T.C., Ferrão L.L., Almada C.N., Santillo A., Albenzio M., Mollakhalili N., Mortazavian A.M., Nascimento J.S., Silva M.C., Freitas M.Q., Sant'Ana A.S., Granato D., Cruz A.G. 2017. Sheep Milk: Physicochemical Characteristics and Relevance for Functional Food Development. Compr. Rev. Food Sci. Food Saf. 16, 247-262.

Bergonier D., De Crémoux R., Rupp R., Lagriffoul G., Berthelot X. 2003. Mastitis Of Dairy Small Ruminants. Vet. Res. 34, 689-716. 
Bianchi L., Casoli C., Pauselli M., Budelli E., Caroli A., Bolla A., Duranti E. 2004. Effect of somatic cell count and lactation stage on sheep milk quality. Ital. J.Anim. Sci. 3, 147-156.

Danków R., Pikul J. 2011. Przydatność technologiczna mleka owczego do przetwórsta. Nauka Przyr. Technol. 5(2), 1-5, ISSN 1897-7820.

Ekici K., Bozkurt H., Isleyici O. 2004. Isolation of Some Pathogens from Raw Milk of Different Milch Animals. Pakistan J. Nutr. 3(3), 161-162.

Ergün Y., Aslantaş Ö., Doğruer G., Kireçci E., Saribay M. K., Ateş C.T., Ülkü A., Demir C. 2009, Prevalence and etiology of subclinical mastitis in Awassi dairy ewes in southern Turkey. Turk. J. Vet. Anim. Sci. 33(6), 477-483.

Fernández-Garayzábal J.F., Fernández E., Las Heras A., Pascual C., Collins M.D., Domínguez L. 1998. Streptococcus parasanguinis: New Pathogen Associated with Asymptomatic Mastitis in Sheep. Emerg. Infec. Dis. 4(4), 645-647.

Jarosińska A., Barłowska J., Wolanciuk A., Pastuszka R., Barłowska K. 2014. Skład chemiczny i jakość mikrobiologiczna mleka towarowego dostarczanego do 5 mleczarni z regionu lubelskiego, z uwzględnieniem sezonu skupu [Chemical composition and microbiological quality of market milk supplied to five dairies in the Lublin region, taking into account the season of purchase]. Rocz. Nauk. PTZ 10(2), 47-56.

Las Heras A., Vela A. I., Fernández E., Legaz E., Domínguez L., Fernández-Garayzábal J.F. 2002. Unusual Outbreak of Clinical Mastitis in Dairy Sheep Caused by Streptococcus equi subsp. Zooepidemicus. J. Clin. Microbiol. 40(3), 1106-1108.

Le Maréchal C., Thiéry R. 2011. Mastitis impact on technological properties of milk and quality of milk products. A review. Dairy Sci. Technol. 91, 247-282

Leitner G., Chaffer M., Caraso Y., Ezra E., Kababea D., Winkler M., Glickman A., Saran A. 2003. Udder infection and milk somatic cell count, NAGase activity and milk composition-fat, protein and lactose - in Israeli-Assaf and Awassi sheep. Small Rumin. Res. 49,157-164.

Markiewicz H. 2013. Wybrane aspekty patogenezy i leczenia ostrej postaci Escherichia coli mastitis u krów. Życie Weter. 88(6), 469-472.

Merin U., Silanikove N., Shapiro F., Bernstein S., Leitner G. 2004. Changes in milk composition as affected by subclinical mastitis in sheep and goats. South Afr. J. Anim. Sci. 34(Suppl. 1), 188-191.

Mørk T., Waage S., Kvitle B., Sviland S. 2007, Clinical mastitis in ewes; bacteriology, epidemiology and clinical features. Acta Vet. Scand. 49(1), 23.

Niedziałek G., Frankowska A., Karkwoswki Ł., Stepan K. 2012. Problemy mastitis u krów z region północno-wschodniej Polski, Zwiastun Naukowy Lwowskiego Narodowego Uniwersytetu Medycyny Weterynaryjnej i Biotechnologii im. S.Z. Gzhytsky, 142(52)2, 396-403.

Olechnowicz J., Jaśkowski J.M. 2005. Komórki somatyczne mleka owczego [Somatic cells in sheep milk]. Med. Wet. 61(2), 136-141.

Pavić V., Antunac N., Mioč B., Ivanković A., Havranek J.L. 2002. Influence of stage of lactation on the chemical composition and physical properties of sheep milk. Czech J. Anim. Sci. 47(2), 80-84.

Pawlik A., Sender G., Oprządek J. 2010. Zapalenie wymienia u krów (cz. 1) [Mastitis in cows (part 1)]. Prz. Hod. 10, 17-19.

Petlane M., Maheswari R.R.A., Noor R.R. 2013, Relationship Between Somatic Cell Counts, Mastitis And Milk Quality In Ettawah Grade And PESA Goats. Agric. Technol. Biol. Sci. 10(6), 607-613.

Pirisi A., Piredda G., Corona M., Pes M., Pintus S., Ledda A. 2000. Influence of Somatic Cell Count On Ewe's Milk Composition, Cheese Yield And Cheese Quality, in: Proceedings of 6th Great Lakes Dairy Sheep Symposium, Ontario, Canada, [b.w.], 47-59.

Rainard P., Corrales J. C., Bel'en Barrio M., Cochard T., Poutrel B. 2003. Leucotoxic Activities of Staphylococcus aureus Strains Isolated from Cows, Ewes, and Goats with Mastitis: Importance of LukM/LukF-PV Leukotoxin. Clin. Diagn. Labor. Immunol. 10(2), 272-277. 
Rozbicka-Wieczorek A., Radzik-Rant A., Puppel K., Czauderna M. 2014. Zawartość składników frakcji białkowej i tłuszczowej mleka owiec wrzosówkowych w zależności od liczby komórek somatycznych [Content of the protein and fat fractions of hairy milk depending on the number of somatic cells]. Rocz. Nauk. Pol. Tow. Zootech. 10(3), 61-69.

Sharma N., Singh N.K., Bhadwal M.S. 2011. Relationship of Somatic Cell Count and Mastitis: An Overview. Asian-Aust. J. Anim. Sci. 24(3), 429-438.

Villalobos J.C., Garzón Sigler A.l., Oliete B., Sánchez R.A, Jiménez L., Núñez Sánchez N., Martínez Marín A.L. 2015. Relationship of somatic cell count and composition and coagulation properties of ewe's milk, Preliminary communication - Prethodno priopćenje, Mljekarstvo 65(2), 138-143.

Watkins G.H., Jones J.E.T. 2007. Mastitis and contagious agalactia, Diseases of Sheep. 4ed. Edinburg, Former Director, Moredun Research Institute, Blackwell Publishing, 99-105.

\title{
SPECYFICZNE CECHY MLEKA OWCZEGO I JEGO WŁAŚCIWOŚCI PROZDROWOTNE W ZALEŻNOŚCI OD LICZBY KOMÓREK SOMATYCZNYCH
}

\begin{abstract}
Streszczenie. Mleko owcze jest cennym produktem ze względu na swoje właściwości i skład. Jest ono bogatsze w białko wysokiej jakości oraz zawiera więcej wartości odżywczych, w porównaniu z mlekiem innych przeżuwaczy. Surowe mleko charakteryzuje się brakiem aktywności enzymatycznej oraz brakiem mikroorganizmów patogennych; cechuje się również dużą zawartością składników mineralnych. $Z$ tego względu jest dobrym surowcem dla przemysłu mleczarskiego i wytwarzania mlecznych napojów fermentowanych, także serów. W czasie laktacji zarówno zawartość poszczególnych składników mleka, jak i wydajność mleczna ulegają wahaniom, co przekłada się na wartość odżywczą produktu. Również zawartość komórek somatycznych w mleku jest istotnie różna między szczytem a zakończeniem laktacji zwierząt. Wzrost elementów komórkowych jest głównym wskaźnikiem infekcji gruczołu mlekowego. Przyczyną mastitis są infekcje na tle bakteryjnym lub mechaniczne uszkodzenie strzyków. Zapalenie gruczołu mlekowego to poważny problem dla hodowców zwierząt mlecznych ze względu na zdrowotne i ekonomiczne aspekty tej choroby, która jest główną przyczyną uboju maciorek oraz upadku wielu zwierząt; wymusza również koszty leczenia samic, przy czym pozyskane mleko jest utylizowane. Szacuje się, że aż do $60 \%$ owiec w stadach może cierpieć na bezobjawowe mastitis, co jest poważnym problemem dla przemysłu mleczarskiego. Dlatego ważne są badania pod kątem analizy ilości komórek somatycznych w mleku.
\end{abstract}

Słowa kluczowe: mleko owcze, mastitis, przemysł mleczarski. 